\title{
BEHOLDING A LANDMARK OF GUILT: PRAMOEDYA IN THE EARLY 1960S AND THE CURRENT REGIME*
}

\section{Ben Abel}

In July 1995 the Ramon Magsaysay Foundation announced the decision to present its annual award to Indonesian writer Pramoedya Ananta Toer. Subsequently, in a protest statement delivered to Manila, twenty-six prominent Indonesian intellectuals expressed their opposition to the award decision, suggesting that the Foundation was not fully aware of Pramoedya's role in "witch-hunting" his fellow writers during "the darkest period for artistic creativity during the 'guided democracy' years (19591965)." 1 Charges of witch-hunting leveled against Pramoedya are nothing new. They have persistently characterized discussions about Pramoedya's role in modern Indonesian literature since the early years of the New Order regime. Branded as a communist even though he was never a member of the PKI, Pramoedya has faced some of the most severe sanctions meted out by the Suharto government to its political opponents. In an atmosphere shaped by both government intimidation and emotional recollections of bitter past disputes, close study of Pramoedya's works, particularly those stemming from the period of his most explicitly political writing, has rarely been undertaken in Indonesia. Consequently, the content of much of this work has been obscured, even as it is periodically invoked by the New Order regime to reinforce its characterization of Pramoedya as a political subversive in Indonesian society. The

\footnotetext{
* This article was presented as a paper at the annual meeting of the Association for Asian Studies, April 11, 1996. I am grateful to the Cornell Southeast Asia Program for providing the financial support for my attendance. Discussion with my colleagues in this panel was invaluable for conceiving and writing this paper. Many thanks to Alex Bardsley, Julie Shackford-Bradley, Sumit Mandal, Amrih Widodo, Caroline Sy Hau, Eveline Ferretti, and Benedict Anderson for their commentary and help in revising early drafts.

1 "Anti-Magsaysay/Pram Reactions." Statement of July 29, 1995. Transmitted on Indonesia-1sia@igc.apc.org, August 9, 1995.
} 
objective of this paper is to address this large gap in the current understanding of Pramoedya and his writing by examining the polemics that situated him as a landmark of guilt in Indonesian society. I do this by examining articles which were published in Lentera, the cultural supplement of Bintang Timur, a daily newspaper which is often assumed to have been published by the PKI during the 1950s and 1960s, but was in fact published by Partindo (Partai Indonesia). ${ }^{2}$

Pramoedya acted as editor of Lentera during the years it was published, between 1962 and 1965. This publication is therefore often cited as proof of Pramoedya's antiliberal extremism, his view of literature as a mere tool for the execution of political projects, and his participation in "literary terror." ${ }^{3}$.Yet these interpretations are misleading. Close reading of some of Pramoedya's most polemical articles in Lentera does reveal the author's distinct political position; they make it clear that he viewed the Indonesian revolution as a fundamental liberation from a feudalistic, colonialist state order, not simply a proclamation of national independence. Far from calling for the subordination of art to politics, however, Pramoedya's writings in Lentera reveal his passionate interest in the socio-political processes shaping Indonesian nationhood, processes which he judged to be the essential font from which identity, viewpoint, and creativity in the writing of post-colonial literature would emerge.

When Lentera was established in 1962, Pramoedya had just been released from imprisonment imposed by the "Orde Lama" because of his opposition to the so-called PP 10/1959, the 1960 government decree against Chinese retailers. Pramoedya's opposition to the decree was publicized in the book Hoa Kiau di Indonesia, which has been banned in Indonesia since its publication. I raise the issue of Pramoedya's imprisonment here because it is important to understand this sequence of events as the context in which Pramoedya wrote for Lentera. The Indonesian military played a central role in both the anti-Chinese campaign and in determining how Pramoedya would be punished for his public oppostion to that campaign.

During Pramoedya's stint in jail, his case was largely ignored by most of his literary colleagues. Many of these same colleagues eventually became known as Manikebuists for their support of the Manifes Kebudayaan (Cultural Manifesto) of 1963, a vaguely worded statement declaring belief in Pancasila to be the "philosophical basis" of Indonesian culture and advocating the equality of all "sectors" in "work[ing] together for this culture to the best of their ability." While they stressed the apolitical nature of art, the Manikebuists were known to have been supported by the army in the latter's struggle against the PKI. As pointed out by historical sociologist Wim Wertheim, the history of Pramoedya's imprisonment by the military, the silence of his colleagues during his jail term, and evidence of the alliances these same colleagues eventually forged with the military all help explain the aggressive criticism of Manikebuist writers voiced by Pramoedya in his writings of the early 1960s. ${ }^{4}$

\footnotetext{
2 It is true that Pratindo had been an allied with the PKI.

3 Ikranagara, "Menghadapi Lekra/PKI (I) Rendra Mengaku Sebagai Perminpin Manifes," Republika 30 (September 30, 1993), and "Menghadapi Lekra/PKI (II) Kalau Begitu Prameodya itu Stalinis," Republika 1 (October 1, 1993)

4 Wim F. Wertheim, "Penghargaan besar buat Pramoedya," Kreasi 19 (1989/1994), p. 16-17. See also

"Pram tentang seorang Pram," Balairung, th. 8 edisi Khusus, 1994, p.122.
} 
Some of Pramoedya's most famous statements in Lentera are found in the series of articles titled "Jang harus dibabat dan harus dibangun." 5 The title alone has been cited as proof of Pramoedya's viciousness in encouraging partisan violence. Goenawan Mohamad, for example, has translated it to mean: "Those who are to be cut down and those who are to be encouraged." 6 However, full consideration of the Javanese literary context from which the title is drawn suggests a different translation. The term "babat" is a Javanese word frequently used in lakon wayang (wayang chronicles), where the phrase "mbabat alas, mbangun deso" refers to "opening the jungle, building a village." Thus, the connotation evoked by Pramoedya's title does not suggest violence against people, but instead carries a message about manipulating the environment to create conditions (space, light, hope) in which people may build communities and livelihoods. In the lore of Javanese mythology, in which kingdoms rise and fall in a cyclical pattern, the phrase calls up the suggestion of beginning ("awakening") society anew. It is significant that Pramoedya chose this evocative Javanese metaphor for his series title and avoided using more direct, less symbolically loaded terms, like tebas or tebang, which mean "to cut" and "to chop." At last, based on a close reading we must conclude that Pramoedya intended to evoke with his imagery a picture of how modern Indonesian might create literature out of its colonial past; he did not mean to recommend the elimination of people.

In the "Jang harus dibabat dan harus dibangun" series Pramoedya argues that Indonesia must dismantle the hegemony of Dutch colonial culture before its writers can create a true post-colonial literature. He singles out for particularly sharp criticism key literary institutions established under the Dutch regime that were carried over into the post-colonial setting. One of these institutions was the Balai Pustaka, the government publishing house established by the Dutch colonial government in 1920 . Pramoedya contended that Balai Pustaka was responsible for the prevailing general ignorance about the history of Indonesian literature in Indonesia because the organization had taken an active role in neutralizing sastra perlawanan (resistance literature). Endowed with the resources of colonial power, the Balai Pustaka was able to bury much of the more political and anti-colonial literature that had appeared in the years prior to its establishment in 1920. Thus made unaware of the true historical development of Indonesian literature, modern Indonesian writers suffered from a "lack of clarity in literary-critical values," according to Pramoedya, leading to "ridiculous" artistic projects with no relevance to the experiences of people at particular historical moments.

\footnotetext{
5 Pramoedya Ananta Toer, "Jang harus dibabat dan harus dibangun," Bintang Timur (Lentera), August 10, 1962, September 1, 1962, September 7, 1962, October 12, 1962 Also "Tahun 1965 tahun pembabatan total," Bintang Timur (Lentera), May 9, 1965

${ }^{6}$ Goenawan Mohamad, The Cultural Manifesto Affair Literature and Politics in Indonesia in the $1960 \mathrm{~s} \mathrm{~A}$ Signatory's View (Clayton: Centre of Southeast Asian Studies, Monash University, 1988), p. 6. Goenawan recently reiterated this understanding, complaining, "He [Pramoedya] strongly criticized writers who did not take a political stand. Such persons, wrote Pram, should be cleared away-we needn't give them even the slightest opportunity." See Goenawan Mohamad, "Pram," Suara independen 3 (August 1, 1995): 50. [Ia mengecam keras penulis yang sikap politiknya tak jelas. Yang semacam ini, tulis Pram, harus dibabat, dan tidak perlu diberikan luang sekecil-kecilnyapun ]

${ }^{7} \mathrm{I}$ am indebted to Amrih Widodo and Ben Anderson for providing this insight.
} 
Another Lentera series written by Pramoedya, entitled "Laporan Tentang Pengadjaran Sastra" (Report on the Teaching of Literature), ${ }^{8}$ featured a major critique of the Indonesian literary establishment as well as intellectuals and political figures. While directing his critique against specific individuals, including Jassin, Teeuw, Takdir, Idrus, Sjahrir, and Muhammad Hatta, Pramoedya actually meant to target the general ideology of universal humanism. For Pramoedya universal humanism is an idealistic system of ideas dreamed up by outsiders and their imitators, who, themselves endowed with great social privilege, pity the unprivileged masses on the one hand, yet on the other fail to share even the smallest part of their own good fortune. Pramoedya charged that the Indonesian literary establishment, misled by these flawed ideas, had accepted and now praised an ideology of humanism that was fundamentally weak, a "humanism without direction."

Pramoedya went on to argue that Indonesian intellectuals who judged the world from their humanist perspective had come to prize a form of intellectualism that sees politics as dirty and art and culture as elevated. He contended that this orientation derived originally from the fatigue, indifference, and pessimism that characterized imperialist governments as a result of their own societies' experiences with the world war and their anti-fascist struggles and that imperialist governments had found a way to use this sorry ideology for their own advantage by introducing it into post-colonial societies. In this way, argued Pramoedya, a spirit of cynicism is encouraged among intellectuals in the newly independent nations even though it is inappropriate for their own situations. Having just emerged from centuries of colonialism, such sentiments hide the "difference" (perbedaan)-essentially, the conflict of interests-between the past colonizers and the once colonized and benefit only the former.

Pramoedya concluded: "universal humanism assisted counter revolutionary forces ... thus betraying real humanism" (ia [humanisme universal] membantu kekuatan kontrarevolusi... [dus] melakukan pengkhianatan terhadap kemanusiaan jang njata). To develop genuine universal humanism, it would be necessary to reject the "Dutch glasses" being imposed by these influences, to turn away from exclusive ideas about aesthetics, and to develop a new perspective that would allow for the study of all kinds of books, however bad, in order to achieve a more grounded understanding of Indonesian culture under imperialism and its aftermath.

When the Manifes Kebudayaan was published in 1963, Pramoedya never addressed the statement directly, but continued his criticism of the universal humanism espoused by the Manikebuists. These biting, often mocking critiques did not go unanswered. In November 1963, a letter written by someone using the pseudonym Buchari was delivered to the Lentera office by $\mathrm{H}$. B. Jassin. This letter was subsequently published by Pramoedya in Lentera with the title, "Is Pram Really a Revolutionary?" (Apakah Bung Pram Memang Revolusioner?) $)^{9}$ The letter recalled various aspects of Pram's work as writer, critic, and revolutionary figure and, on that basis, charged Pramoedya with

${ }^{8}$ In Bintang Timur (Lentera), April 21, 1963, April 28, 1963, May 5, 1963, May 12, 1963, May 19, 1963, May 26, 1963, June 2, 1963, June 9, 1963, June 23, 1963, June 30, 1963, July 7, 1963, and July 14, 1963. For a more complete explanation of this series of articles, see Steven Miller, "Pramoedya and Politics : Pramoedya Ananta Toer and Literary Politics in Indonesia, 1962-1965," BA honorary thesis, Australian National University, 1992, pp. 28-31.

9 Buchari, "Apakah Bung Pram Memang Revolusiorer," Bintang Timur (Lentera), November 10, 1963. 
hypocrisy, deficient nationalism, and a failure to grasp the true meaning of the Manikebu position. As Buchari observed, Pramoedya himself was known to have been involved with and gained benefits from the very institutions he so sharply criticized (Sticusa, Balai Pustaka, and others). The book Hoa Kiau di Indonesia represented a threat to the Indonesian revolution, and the fact that Pramoedya remained unable to recognize the government's ban of the book as a pro-revolutionary act showed that he did not comprehend the Indonesian people's true interests. Regarding the Cultural Manifesto, Buchari charged that Pram clearly had the wrong "attitude" (sikap). As implied in the Manifesto, artists should not be opposing their fellows, but should be striving to save the divine nature of all people (a phrase that echoed the tenets of universal humanism). Raising doubts about Pramoedya's own nationalism, the letter pointed out Lentera's tendency to include articles that appeared to promote "foreign," that is, Chinese, literature and culture, and cited those Chinese articles as evidence that Pramoedya himself knew little of the Indonesian people in their totality and failed to appreciate their Pancasila national aspirations.

Buchari's first letter triggered a brief exchange between Pramoedya and this critic in which the specific points raised by the other were systematically refuted. ${ }^{10}$ The exchange revealed significant differences in argument. Pramoedya criticized Buchari for his display of prejudice against so-called "foreigners" (i.e. Chinese) which, he said, appeared to be blinding the author the very influences that had shaped Indonesia and to the true nature of the problems facing the post-colonial nation. Clearly only a transformation of the overall economic system would bring prosperity to the Indonesian people, not mere alterations in the ethnic make-up of capital owners, alterations that the anti-Chinese legislation was meant to accomplish. Buchari, for his part, continued to support the essential correctness of the government policy designed to constrain dominant Chinese entrepreneurs in the Indonesian economy.

The exchange between Buchari and Pramoedya demonstrates critical distinctions in how the direction of the Indonesian revolution and the project of nation-building was being conceptualized by the two writers. In the strong exception Buchari takes to Hoa Kiau di Indonesia and the "foreign" content of Lentera, we see a preoccupation with construction of ethnic identity, framed here as the "foreignness" of the Chinese. As scholars of modern Indonesian history have pointed out, 11 this preoccupation was inherited from Dutch colonial policy. Buchari's view of the Indonesian revolution and the subsequent process of building a post-colonial "Pancasila" state is contained inside a framework that strictly demarcates the boundaries of ethnic identity. Within this framework, concepts of "foreignness" and "Indonesianness" shape perceptions of the revolutionary struggle. Actions or words that challenge these borders are in turn defined as a basic threat to the revolution itself. Pramoedya's imprisonment for publishing Hoa Kiau di Indonesia is thus construed as a "revolutionary" act; discussion

10 "Pramoedya Ananta Toer mendjawab," Bintang Timur (Lentera), November 10, 1963; "Mengamankan Djawaban Pramoedya Ananta Toer," Bintang Timur (Lentera), November 17, 1963; "Djawaban Bung Pram," Bintang Tirnur (Lentera), November 17, 1963.

${ }^{11}$ Ben Anderson's speech at the Indonesian Students Meeting in Ithaca, December 27, 1994. Later appeared in apakabar@clark.net Thursday, December 7, 1995, with subject: IN: Ben Anderson: Cina di Indonesia. 
of "foreign" materials in Lentera's columns is seen as subversion of the Indonesian people and their revolution.

Pramoedya's observations contrast with Buchari's position by stressing the international nature of the influences shaping Indonesia as a nation-in-the-making. Examined from this perspective, the activity of establishing borders does not figure as the essential marker of the nation-building project. Rather, Pramoedya argues that encouraging exclusivity as one attempts to build a nation will result in "simple prejudice" useless for analyzing of who is the true revolutionary and who is not. Here the writer discusses the process of changing an unequal social system ("If it is said: 'be freed from outside influence,' this means we should be freed from subordination to those influences, not that we should blindly reject them." ${ }^{12}$. Within this framework, the project of social change-not border control-becomes the defining element of the Indonesian revolution and the post-revolutionary process.

Ironically, of course, the contrast between Buchari and Pramoedya reveals the hypocrisy of the former's claim to abide by "universal humanism" and illuminates Pramoedya as the true humanist. Pramoedya's position on the Indonesian revolutionary process ties in closely with his critique of universal humanism in other ways as well. His writings contend that the development of modern Indonesian literature must be grounded in the sober recognition of the basic conflicts of interest existing between people of different levels of "social privilege," conflicts of interest underlying any inequitable socio-economic regime, and that Indonesian literature gains very little from an ideology preoccupied with "universal commonality." Historical consciousness is essential for writers because writers must recognize that social conflict underlies the development of Indonesian literature itself-early writers wrote out of a position of social subordination relative to the Dutch, a position underplayed or ignored by some, but which for many others became the very source of their inspiration to write.

Pramoedya's attitude towards universal humanism grows from particular notions about the relationship between writers as artists and the socio-political context in which they work. He clearly conceived the act of writing to be located within the process of socio-political change, not separated from it as a transcendent attempt to reflect human commonality. He argued that, in the heat of the Indonesian revolutionary challenge to a regime organizing the conditions of everyday life in the Dutch East Indies, it was impossible to separate Indonesian writers from their particular position as members of a subordinate group. Similarly, it was also impossible in the 1960s to separate modern writers from their political roles as people who were, like it or not, involved in the post-colonial socio-economic regime and the political struggles generated by it. Thus, Pramoedya saw writers as political actors whose identities are necessarily shaped by the conditions of their respective historical contexts.

By defining writers as political actors, Pramoedya attracted severe criticism from those who accused him of adhering to the notion of "politics in command." Even

12 "Kalau dikata 'telah bebas dari pengaruh luar' itu berarti bahwa kita bebas dari perbudakan atas pengaruh itu, bukan kita menolak pengaruh secara membabibuta." "Djawaban Bung Pram," Bintang Timur (Lentera), November 17, 1963. 
today, the Manikebuists define this notion as one that advocates the use of literature as a political tool. In other words, it is interpreted to mean that "party (PKI) politics should direct art."13 A different interpretation is possible, however; for instance, one might argue that the phrase asserts politics are central to the criticism of literature because politics can illuminate literature in the process of its own creation. In other words, based on the reading of Pramoedya's writings in Lentera, I suggest that Pramoedya argued not that literature should be used for politics, but that politics should be used as a tool to criticize and understand literature according to the development of the revolution at that time. Pramoedya understood the writing of literature not as removed from the "dirty" arena of politics, but as itself a highly fractious process, in which dissonance and contention are real and are creative rather than illusory or undesirable conditions of human experience. This perspective may have contributed to the strength of Pramoedya's own later historical fiction (the Karya Buru tetralogy) in which, as Foulcher observes, Pramoedya "stands clear of the nationalist mythology of the post-colonial state" and "stresses hybridity and the negotiation of the marginal condition."14

Pramoedya's polemics are rooted in particular ideas about the meaning of revolution, post-colonial nation building, and Indonesian writers' relationship to these processes. In a statement a few years ago, Pramoedya explained his own objective in founding and writing for Lentera by saying that he wished to inform a constructive system for understanding, teaching, and ultimately creating literature. ${ }^{15}$ More recently, however, he has admitted an essential flaw in his project: writers should be writers, he says now, and literary critics should be literary critics, and he regrets having at one time attempted to take on both roles as one person. ${ }^{16}$ In my opinion, this statement acknowledges Pramoedya's discovery that a writer who attempts to critique his or her own media may well encounter a potential conflict of interest, for that writer may discover that investment in one's own career inevitably tends to personalize the debate and tempts one to defend positions because of what they signify for one's career, rather than what they signify for the actual process of creating literary works. Despite this pitfall, Pramoedya's arguments regarding writers and politics resonate with many Indonesians of various backgrounds and disciplines today. It is possible that the

13 Steven Miller explained that for some reason Goenawan consistently represents the slogan as Politik Sebagai Panglima (Politics as the Commander), rather than Politik Adalah Panglima (Politics in Command). Goenawan's version of the slogan allows less space for the type of interpretation Pramoedya sometimes gives it in his work-i e. that politics is central to the understanding of art rather-rather than the standard post-1965 interpretation that always interprets it as meaning "party (PKI) politics should direct art." All of Miller's other sources quote the slogan as "Politik Adalah Panglima " See Steven Miller, "Pramoedya and Politics," p. 21,

14 Keith Foulcher, "In Search of the Postcolonial in Indonesian Literature," Sojourn 10,.2 (October 1995): 163 See also I Gusti Agung Ayu Ratih, "Rushdie dan Pramoedya: Bersimpangnya narasi tentang bangsa," Kalam 6 (1995): 49. "Mereka kembali melacak asal-usul bangsanya dalam usahanya mengingat sekaligus memulihkan cita-cita awal kemerdekaan"

15 Pramoedya Ananta Toer, "Melengkapi menghadapi Lekra/PKI" (I) dan (Il), unpublished letter, 1993, p. 14

16 "Saya menyesal telah membuat kritik sastra pada masa lalu. KaIau bisa, jadi pengarang ya pengarang saja, kalau jadi kritikus, ya kritikus saja Kalau pengarang jadi kritikus ukurannya adalah dirinya, pengalamannya, pikirannya dan prestastinya sendiri. Ini tidak etis Saya menyesal menulis kritik sasra." From an interview for Mutiara (September 19-25, 1995), p 778. 
visions of revolution, nation, and writing he articulated in Lentera, however incompletely or problematically, hold hope for "a distinctive type of postcolonial literature" 17 in the coming years.

${ }^{17}$ Foulcher, "In Search of the Postcolonial," p. 168. 